\title{
Analysis of Structural Shifts in Employment Among Crimean Youth
}

\author{
Elena Polishchuk ${ }^{1},{ }^{*}$ Natalia Stakhno ${ }^{1}$, Olga Pochupailo ${ }^{1}$ \\ ${ }^{1}$ V.I. Vernadsky Crimean Federal University, Simferopol, Russia \\ *Email:pea.znu@mail.ru
}

\begin{abstract}
The application of the structural shifts method allowed the study to assess the key indicator of the labor market - youth employment. The process of assessing changes in the number of employed youth on the example of the Republic of Crimea was carried out in relation to the national level (assessing the difference between the actual and acceptable growth that could take place in the republic, if it was characterized by the production structure identical to the national one). The study made possible a new analysis of differential and proportional shifts in the employment of young people on the registered labor market of the Republic of Crimea, assess the impact of national and regional development features that influenced the change of the indicator in question, which, of course, had an impact on the labor market conditions in the region.
\end{abstract}

Keywords: Labor market, Structural shift, Employment, Conjuncture, Youth, Type of economic activity, Localization coefficient.

\section{INTRODUCTION}

The Law "On the Strategy for Socio-Economic Development of the Republic of Crimea until 2030" lays down the main priorities for the development of the Crimean region, which necessitates improving the balanced reproduction of workers and qualified personnel and their effective use in the labor market.

Based on the need to identify the characteristics of the youth labor market in the Republic of Crimea, an assessment of its main components - labor supply and demand - was carried out.

The survey was based on information from Rosstat, Krymstat and the State Employment Centre, which provides an extensive range of public services, one of which is helping citizens of the Republic, including young people, to find suitable employment (supply) and employers to find the right people (demand).

\section{RESEARCH METHODS}

The need to identify characteristic features of the registered labor market in the Republic of Crimea has contributed to the assessment of one of its basic indicators - youth employment by the main types of economic activity.

To identify the types of economic activities that contribute to the increase in the number of employed youth, a comparative study of this category in the labor market of the Russian Federation and the Republic of Crimea was conducted for two years (2014 and 2019) using the basic method of structural shifts, the essence of which is to estimate the change in the number of employed youth at the level of a particular region (entity) [1-5], relative to the national level (estimating the difference between the actual and the acceptable growth that could take place in the region). The application of this method in this study allows a new analysis of quantitative shifts in youth employment in the registered labor market of the Republic of Crimea.

\section{FINDINGS}

The overall shift (S) of each component demonstrates the discrepancy between the actual regional change and the change that could have occurred under the condition of regional development at 
the state-wide rate. In turn, the overall shift consists of two components: differential $\left(\mathrm{S}_{\mathrm{d}}\right)$ and proportional $\left(\mathrm{S}_{\mathrm{p}}\right)$ [4-6].

Table 1 presents initial data - the number of employed young people in the registered labor market in the Russian Federation as a whole and in the Republic of Crimea in particular, broken down by the main types of economic activity.

The analysis of the data presented in the table allows us to conclude that during the studied period the number of employed youth in the registered labor market of the Republic of Crimea increased by 1.5 times (by 60.7 thousand people), especially by types of economic activity (agriculture, hunting and forestry; industry; hotels and restaurants, etc.), which is determined by the Strategy of social and economic development of the Republic of Crimea until 2030; while at the national level there was a decrease in the number of employed youth by 2666 thousand people, e.g. agriculture, hunting and forestry; building; transport and communications; real estate, renting and services, etc.

The results of the calculations of structural shifts reflecting specific transformations of youth employment in the registered labor market are shown in table 2.

The resulting value of the overall structural shift $(S=79.6)$ indicates that the growth rate of youth employment in the registered labor market of the Republic of Crimea is higher than the average for the Russian Federation. The positive value of $S_{d}$ confirms an increase in the number of employed young people in all types of economic activity under consideration. At the same time, a positive value of $S_{p}$ means that certain types of economic activity are developing dynamically in the Republic of Crimea, the growth rate of youth

Table 1. Distribution of employed youth in the registered labor market by main type of economic activity

\begin{tabular}{|c|c|c|c|c|c|c|c|c|}
\hline \multirow{3}{*}{ Type of economic activity } & \multicolumn{4}{|c|}{ Russian Federation } & \multicolumn{4}{|c|}{ Republic of Crimea } \\
\hline & \multicolumn{2}{|c|}{2014} & \multicolumn{2}{|c|}{2019} & \multicolumn{2}{|c|}{2014} & \multicolumn{2}{|c|}{2019} \\
\hline & $\begin{array}{c}1000 \\
\text { people }\end{array}$ & $\%$ & $\begin{array}{c}1000 \\
\text { people }\end{array}$ & $\%$ & $\begin{array}{c}1000 \\
\text { people }\end{array}$ & $\%$ & $\begin{array}{c}1000 \\
\text { people }\end{array}$ & $\%$ \\
\hline TOTAL & 17575 & 100.0 & 14909 & 100.0 & 112.9 & 100.0 & 173.6 & 100.0 \\
\hline Agriculture, hunting and forestry & 1030 & 5.8 & 739 & 4.9 & 6.7 & 5.9 & 9.9 & 5.7 \\
\hline Fishing, fish farming & 16 & 0.1 & 12 & 0.1 & 1.0 & 0.9 & 1.8 & 1.0 \\
\hline Mining & 271 & 1.5 & 326 & 2.3 & 1.1 & 1.0 & 2.5 & 1.4 \\
\hline Manufacturing industries & 2751 & 15.6 & 1952 & 13.1 & 15.6 & 13.8 & 21.9 & 12.6 \\
\hline $\begin{array}{l}\text { Production and distribution of } \\
\text { electricity, gas and water }\end{array}$ & 351 & 2.0 & 375 & 2.5 & 1.7 & 1.5 & 2.7 & 1.6 \\
\hline Building & 1493 & 8.5 & 1113 & 7.5 & 6.3 & 5.7 & 10.2 & 6.0 \\
\hline $\begin{array}{l}\text { Wholesale and retail trade; repair } \\
\text { of motor vehicles, motorbikes, } \\
\text { household products and personal } \\
\text { goods }\end{array}$ & 3472 & 19.8 & 3005 & 20.2 & 12.6 & 11.2 & 20.5 & 11.8 \\
\hline Hotels and restaurants & 451 & 2.6 & 560 & 3.8 & 2.4 & 2.1 & 4.7 & 2.7 \\
\hline Transport and communications & 1514 & 8.6 & 1105 & 7.4 & 11.4 & 10.1 & 16.5 & 9.5 \\
\hline $\begin{array}{l}\text { Real estate operations, renting and } \\
\text { services }\end{array}$ & 1078 & 6.1 & 168 & 1.1 & 4.8 & 4.2 & 8.4 & 4.8 \\
\hline Education & 1153 & 6.6 & 1037 & 6.9 & 13.9 & 12.3 & 19.7 & 11.3 \\
\hline Health and social service provision & 924 & 5.3 & 858 & 5.7 & 15.8 & 14.0 & 22.9 & 13.2 \\
\hline $\begin{array}{l}\text { Provision of other communal, social } \\
\text { and personal services (excluding } \\
\text { community association activities) }\end{array}$ & 646 & 3.7 & 420 & 2.8 & 4.2 & 3.7 & 6.8 & 3.9 \\
\hline Other economic activities & 2425 & 13.8 & 3239 & 21.7 & 15.4 & 13.6 & 25.1 & 14.5 \\
\hline
\end{tabular}

Source: Calculations made by the authors. 
Table 2. Structural shifts and growth rates of youth employment in the registered labor market of the Republic of Crimea by economic activity in 2014 and 2019

\begin{tabular}{|c|c|c|c|c|c|}
\hline \multirow[b]{2}{*}{ Type of economic activity } & \multirow[b]{2}{*}{ Sd } & \multirow[b]{2}{*}{ Sp } & \multirow[b]{2}{*}{ S } & \multicolumn{2}{|c|}{$\begin{array}{l}\text { Employment growth rate in the } \\
\text { registered labor market } 2019 / 2014, \%\end{array}$} \\
\hline & & & & $\begin{array}{l}\text { Russian } \\
\text { Federation }\end{array}$ & $\begin{array}{l}\text { Republic } \\
\text { of Crimea }\end{array}$ \\
\hline TOTAL & 77.2 & 2.4 & 79.6 & 84.8 & 153.8 \\
\hline Agriculture, hunting and forestry & 5.1 & -0.9 & 4.2 & 71.7 & 147.8 \\
\hline Fishing, fish farming & 1.1 & -0.1 & 1.0 & 75.0 & 180.0 \\
\hline Mining & 1.2 & 0.4 & 1.6 & 120.3 & 227.3 \\
\hline Manufacturing industries & 10.8 & -2.2 & 8.6 & 70.9 & 140.4 \\
\hline $\begin{array}{l}\text { Production and distribution of electricity, gas and } \\
\text { water }\end{array}$ & 2.3 & 0.4 & 2.7 & 106.8 & 158.8 \\
\hline Building & 5.5 & -0.6 & 4.9 & 74.5 & 161.9 \\
\hline $\begin{array}{l}\text { Wholesale and retail trade; repair of motor } \\
\text { vehicles, motorbikes, household products and } \\
\text { personal goods }\end{array}$ & 9.6 & 0.3 & 9.9 & 86.5 & 162.7 \\
\hline Hotels and restaurants & 1.7 & 0.9 & 2.6 & 124.2 & 195.8 \\
\hline Transport and communications & 8.2 & -1.4 & 6.8 & 72.9 & 144.7 \\
\hline Real estate operations, renting and services & 7.7 & -3.3 & 4.4 & 15.6 & 175.0 \\
\hline Education & 7.2 & 0.7 & 7.9 & 89.9 & 141.7 \\
\hline Health and social service provision & 8.2 & 1.3 & 9.5 & 92.9 & 144.9 \\
\hline $\begin{array}{l}\text { Provision of other communal, social and personal } \\
\text { services (excluding community association } \\
\text { activities) }\end{array}$ & 4.1 & -0.8 & 3.3 & 65.0 & 161.9 \\
\hline Other economic activities & 4.5 & 7.7 & 12.2 & 133.6 & 163.0 \\
\hline
\end{tabular}

Source: Calculations made by the authors.

employment in the registered labor market of which exceeds the national average.

The calculations show that, for all types of economic activity, the growth rate of youth employment in the registered labor market in 2019 exceeded the national average compared to 2014.

It is directly linked to the active transformational processes taking place in the regional economy: the reactivation of most organizations (enterprises) that reregistered in 2015, which left part-time employment mode and began the modernization process that created the need for new staff; implementation since 2015 of a set of measures related to the realization of key state programmes, whose objectives are aimed at increasing youth employment as the main source of replenishing and renewing the labor force (temporary jobs, creation of additional jobs, advanced training for employees of organizations, etc.) at the labor market.

Many studies with the applied method [3, 5, 6-11] use the localization coefficient $\left(\mathrm{L}_{\mathrm{i}}\right)$, the calculation of which is carried out in order to determine both the degree of specialization of the subject (region) in a particular type of economic activity and the level of its concentration in the subject (region), taking into account the comparison of the regional branch structure with the nationwide structure.

Consideration of the values of the coefficient in question has made it possible to divide types of economic activity into the following groups:

- basic (prospective) with $\mathrm{L}_{\mathrm{i}}>1.25$, indicating their significant concentration in the region (subject);

- local, serving the needs of the intraregional market and forming the current specialization of the region (subject): $\mathrm{L}_{\mathrm{i}}$ from 0.75 to 1.25 ;

- non-typical, not related to the types of economic activity of which the subject (region) specializes during the period under study: $\mathrm{L}_{\mathrm{i}}<0.75$.

\section{CONCLUSION}

The study concluded that $\mathrm{Li}$ exceeded 1.25 for six economic activities, with the highest $\mathrm{Li}$ values being in fisheries, fish farming (10); real estate, rental and service operations (4.36); health and social services (2.32), etc.

Four types of economic activities in 2019 were included in the local group forming the current specialization of the Republic of Crimea: agriculture, 
hunting and forestry (1.16); manufacturing industries (0.96); building (0.8); and hotels and restaurants (0.75).

The group of non-typical for the Republic of Crimea in 2019 included four types of economic activity: mining (0.61); production and distribution of electricity, gas and water (0.64); wholesale and retail trade; repair of motor vehicles, motorbikes, household products and personal goods (0.58); other economic activities (0.67).

The method used in the study made it possible to study the dynamics of youth employment in the registered labor market of the Republic of Crimea, to assess the impact of national and regional development features on the changes in the indicator in question, which, no doubt, affected the modification of the labor market conditions during the analyzed period.

\section{REFERENCES}

[1] L.A. Filho, Labour market and turnover in the industrial employment in the Brazilian Northeast region, Investigación Económica 75 (2016) 203230.

DOI: http://dx.doi.org/10.1016/j.inveco.2016.03.006

[2] M. Dütsch, F. Ganesch, O. Struck, Employment trajectories in heterogeneous regions: Evidence from Germany, Advances in Life Course Research 40 (2019) 43-84. DOI: https://doi.org/10.1016/j.alcr.2019.03.002

[3] V.V. Mischenko, A.G. Elistrarova, Evaluation of the state of regional labor market based on the analysis of structural changes in economics, Economics, profession, business 4 (2016) 46-51.

[4] Yu.G. Byuraeva, Comparative analysis of structural shifts in employment in Baikal region site, Proceedings of the Irkutsk state academy of economics (Baikal state university of economics and law), No. 2, 2011. Retrieved from: https://elibrary.ru/item.asp?id=15630864

[5] Yu.G. Byuraeva, The analysis of the structure of employment of Transbaikalian region (Republic Buryatiya and Transbaikalian Area), Labor and Social Relations Journal 9 (2012) 24-32.

[6] E.A. Polishchuk, Assessment of the basic components of the labour market on the basis of shift-share analysis, Management of economic systems: scientific electronic journal, No. 8(114), 2018. Retrieved from: http//www.uecs.ru

[7] F. Belloc, M. D'Antoni, The Elusive Effect of Employment Protection on Labor Turnover, Structural Change and Economic Dynamics 54 (2020) 11-25. DOI: https://doi.org/10.1016/j.strueco.2020.04.001
[8] G.N. Stroeva, Structural changes in employment the population of the Khabarovsk krai, Scientists notes PNU 4(5) (2014) 1392-1398.

[9] P. Sarkar, Does labor regulation reduce total and youth employment? Structural Change and Economic Dynamics 52 (2020) 374-381. DOI: https://doi.org/10.1016/j.strueco.2019.12.010

[10] T.V. Sarycheva, Comparative analysis of structural changes in the population of the Republic of Mari El, Economics, Statistics and Informatics 2 (2012) $170-176$

[11] Y. Ding, Z. Li, X. Ge, Yu. Hu, Empirical analysis of the synergy of the three sectors' development and labor employment, Technological Forecasting and Social Change 160 (2020) 120-223. DOI: https://doi.org/10.1016/j.techfore.2020.120223 